\title{
Introduction: The nineteenth century in a nutshell
}

The "Wandering Jew" made his way to Sweden long before any actual Jewish immigrants were allowed to settle in the country. And he was very popular: between 1800 and 1900 alone, 26 editions of the medieval legend of Ahasver were printed in publishing houses all over the country, most often accompanied by two other anti-Jewish texts of medieval origin. " "The Legend of Judas the Traitor" (Legenden om förrädaren Judas) was another very popular text; with 15 editions during the nineteenth century, the legend closely following the version from Jacobus de Voragine's Legenda aurea and its thirteenth-century East Norse translation Fornsvenska legendariet.

Medieval anti-Jewish texts not only remained intelligible, they were also widely used and read in the period when Emancipation was being fiercely debated - and repeatedly rejected. They conveyed religious motifs of Jew-hatred such as deicide, punitive supersessionism (the idea that Jewish diaspora was a punishment for the deicide), bloodthirstiness, and bad character, but they also conveyed essentialist and racist ideas, such as there being a specific, repulsive "Jewish physiognomy" and Jews being an eternal, unchangeable collectivity. In addition to the contemporary ideas about Jews and Judaism that were developed and discussed in relation to the status of the Jewish minority in the country, these medieval motifs were and remained part of the collective "knowledge" about Jews as an imagined collectivity. What does this mean for the development of modern antisemitism in Sweden? Why were these medieval texts so popular?

In 1782, the first Jews were allowed to settle in Sweden, their immigration heavily regulated regarding numbers, demographics, economic standing, and place of settlement. The royal decree allowing this was called the judereglemente. ${ }^{2}$ In the first decades after it was enacted, parliament and government already had misgivings regarding any Jewish presence in the country. In 1806, King Gustav IV Adolf revoked some of the liberties granted to Jews, and his decree against any further Jewish immigration was printed several times and distribut-

1 Om thet straff hwart släkte bland judarne i synnerhet lida måste (On the punishment which each tribe of the Jews has to suffer specifically), also with variations of the title (Punishment of the Twelve Tribes, Story of the Twelve Tribes etc.), and Om Pilati död och oroliga döda kropp (On the death of Pilate and his unruly dead body). See below, Chapter 2.

2 Judereglemente: "Reglemente för dem av Judiska Nationen, som vilja hit i Riket inflytta och sig här nedsätta," in Urkunder till judarnas historia i Sverige, ed. Hugo Valentin (Stockholm: Bonnier, 1924). For a more thorough discussion of its contents, see below, Chapter 4.

Ә OpenAccess. (C) $2022 \mathrm{He}$, published by De Gruyter. (cc) BY-NC-ND This work is licensed under the Creative Commons Attribution-NonCommercial-NoDerivatives 4.0 International License.

https://doi.org/10.1515/9783110757408-003 
ed. ${ }^{3}$ In 1815 , two proposals were made in the Riksdag to restrict Jewish rights even more than already stated in the judereglemente and in Gustav's amendment. ${ }^{4}$ The Jews made a submission to the special committee at the Riksdag in order to defend their case and to ask instead for a liberalization of the judereglemente. As was the case with many proposals, statements, and speeches of public interest that were submitted to the Riksdag, this one was published. ${ }^{5}$ All submitted proposals were rejected by the commissions preparing the debates, and this provoked a number of fierce diatribes against Jews in general and against Jews in Sweden in particular. Proposals made during this debate included deporting all Jews from Sweden, confiscating their goods, forced conversion, forced baptism of Jewish children, placing Jewish children in Christian families, and other measures intended to erase all Jewish presence from Sweden. Like Denmark in 1813 and Norway a few years later, Sweden experienced a judefejd (Jewish feud) in 1815.

The few publications which have dealt with the judefejden of 1815 in Sweden have examined its actors and motifs as if the debate were a relatively isolated event - no political decisions were made, no violence broke out, it would be decades before the next major public debate on the matter. But if we change the focal point of analysis from the text production immediately connected to the judefejden and look instead at where the publicists most likely got their information on Jewish topics and what their readers had access to besides the products of the quarrel itself, this and other outbreaks can be seen as the results of a constant stream of anti-Jewish knowledge production in various text genres. In the print production of that year, a specifically Swedish combination of religious, economic, cultural, and political arguments can be observed as having already developed fully into a distinctively racist and determinist form of Christian antisemitism. Political pamphlets were accompanied by the medieval legends of Ahasver and Judas, by conversion stories, novels, and entertaining satirical dialogues in which Jews were described as a race, a state within the state, a foulsmelling and sick collectivity of individuals still bearing the blood curse and sucking money and life from their host societies. Probably because the literary antisemitism of 1815 did not lead to outbreaks of violence, this event has generally been discussed in connection with the flourishing forms of personal polem-

3 Kongl. Maj:ts och Rikets Commerce-Collegii kungörelse, angående förbud för judar att i riket inkomma. Gifwen Stockholm den 19 december 1806 (Stockholm: Kongl. Tryckeriet, 1806).

4 See the appendix for an overview of the debates about Jewish issues in the Riksdagen.

5 Judiska nationens härvarande föreståndares förklaring till rikets höglofl. ständers särskilta utskott vid riksdagen år 1815, tillika med högbemälte utskotts 2:ne betänkanden till rikets ständer, angående ändringar i jude-reglementet (Stockholm: Carl Delén, 1815). 
ics and political satire also in evidence in many of the publications in question. Furthermore, its chronological coincidence with the flood of anti-Jewish publications on the continent, particularly in Germany, which ultimately led to the HepHep riots in 1819, has been largely ignored. As has the fact that, besides the many original Swedish products, books from well-known German opponents of Jewish Emancipation - such as Friedrich Buchholz, one of the most prolific and influential publicists in Berlin since 1800 - were translated and published that same year. ${ }^{6}$

It was an eventful year in Europe, what with the defeat of the Napoleonic armies. A depression followed in Sweden, which involved a number of large businesses going bankrupt - some of them owned by Jews. ${ }^{7}$ This sparked accusations of shady business practices focused specifically on the Jewish owners, the main lines of this argument having already been established during the previous years. The debate also constituted the first serious attempt to tighten restrictions on Jewish immigration, thirty-five years after the establishment of the first communities - or, more generally, to re-examine these restrictions. Despite the limits on immigration and the initial restriction of Jewish settlement to Stockholm, Gothenburg, and Norrköping, Jews had been allowed to settle in two additional towns since 1811, namely, Arvika and Töksmark in Värmland, a rural mountain area. Even though quantitatively minuscule, the Jewish minority in Sweden probably seemed to be growing in importance in 1815 and, additionally, was becoming increasingly visible in the world of business - a hot topic at the time, given the antiquated, protectionist, inflexible laws governing trade, manufacturing, and craftsmanship.

6 Thomas Thaarup and Friedrich Buchholz, Lurifaxiana. 1.-2. häftet. Närvarande förhållande emellan judar och kristne $i$ intellektuelt och moraliskt hänseende, Öfversättning (Stockholm: Olof Grahn, 1815). The antisemitism of this text provoked a response, Lurifalsiana eller den tilltvålade Lurifaxiana, by Heinrich Heilborn, who had emigrated from Hamburg to Stockholm and worked in Benedicks's company. On Buchholz generally and his complicated relation to the “Jewish question," see Iwan-Michelangelo D’Aprile, Die Erfindung der Zeitgeschichte: Geschichtsschreibung und Journalismus zwischen Aufklärung und Vormärz. Mit einer Edition von 93 Briefen von Friedrich Buchholz an Johann Friedrich Cotta und Johann Georg Cotta, 1805-1833 (Berlin: Akademie Verlag, 2016).

7 Henrik Edgren names seven out of twenty bancruptcies as belonging to Jewish businesses. Henrik Edgren, "Societal Change, Economic Decline and National Identity: The Debate About Jews in Sweden in the Early Nineteenth Century," in The Exclusion of Jews in the Norwegian Constitution of 1814: Origins - Contexts - Consequences, ed. Christhard Hoffmann, Studien zum Antisemitismus in Europa 10 (Berlin: Metropol, 2016); Ernst Meyer, "Die Literatur für und wider die Juden in Schweden im Jahre 1815," Monatsschrift für Geschichte und Wissenschaft des Judentums 51, no. 5 (1907). 
Two main factions appeared in the Riksdag: On one side were the bourgeois and noble members of parliament. Baron Johan Ludvig Boije was their most prolific author, with 27 texts on the topic in 1815. On the other side, Otto Fredrik Påhlman, who defended the Jewish presence in Sweden and called for a liberalization of the judereglemente. ${ }^{8}$ The author and agitator Carl August Grevesmöhlen joined in, publishing roughly 60 texts in 1815 alone. The public dialogue and dispute between Grevesmöhlen and Boije was central to the debate; their texts used the Jewish question as an opportunity to debate liberalism, the national economy, and constitutional matters. Even though their feud was the catalyst for a sudden and wide-ranging production of anti-Jewish texts, Swedish historiography has labelled the whole episode the "Grevesmöhlska striden," thereby neglecting the significance it held for establishing and developing anti-Jewish hostility in Sweden. In the polemic between these two figures one can discern a lot of personal anger, big egos, and grandstanding, but very little in the way of serious or innovative statements regarding the "Jewish question." Yet nineteenth century Sweden's most important literary and political conflict regarding Jewish Emancipation developed out of their petty quarrel.

Grevesmöhlen, even though he was engaged in a harsh polemic against Boije and his strict opposition to any Jewish presence in Sweden, was by no means a friend of Jews - his contributions are sarcastic and half-hearted, describing Jews as a collectivity with certain shared negative traits. Furthermore, he only got involved after the debate had already been going on for several months in both printed books and the Riksdag. It had been initiated by the members of parliament Gustav Stabeck and Johan Wegelin (both belonging to the estate of the burghers), who proposed the judereglemente be revoked and all Jews expelled from the country, pointing to their allegedly maleficent business practices and usury. The proposals were produced as independent leaflets by printers in Stockholm and thus spread outside the parliamentary arena. ${ }^{9}$ One of the first counterarguments to Grevesmöhlen was Fredrik Cederborgh's pamphlet Judar

8 A response to his original intervention was published: Erinringar vid herr O.F. Påhlmans yttrande i höglofl. ridderskapets och adelns plenum, d. 13 april 1815, angående judarna (Stockholm: Carl Nyberg, 1815).

9 Johan Wegelin, Memorial om nödige förändringar uti kongl. commerce-collegii reglemente af den 27 maij 1782 för de i riket inflyttade och bosatte medlemmar af judiska nationen, af J. Wegelin G:son. Upläst i vällofl. borgare-ståndets plenum den 1 maij: 1815 och på ståndets begäran till trycket lämnadt (Stockholm: Peter Sohm, 1815); Gustaf Stabeck, Memorial, uppläst i riksens höglofl. ständers allmänna beswärs- och ekonomi-utskott den 7 julii 1812, innehållande dels tillägg och dels anmärkningar emot samma utskotts betänkande, rörande manufacturernas och fabriquernas upphjelpande (Stockholm: Olof Grahn, 1815). 
äro judar och blifva i evighet judar. ${ }^{10}$ It is written from the perspective of a capitalist who profits from the Jews' unfair and cruel business and trading practices. An anonymous author devoted roughly half of his pamphlet Viva-Rop för Grevesmöhlen, Påhlman och Judarne ${ }^{11}$ to polemical attacks against the men named in its title. ${ }^{12}$ In both texts, religious and economic stereotypes are merged within the principal theme of egennytta vs statens nytta (self-interest vs common good), ascribing selfishness to all Jews and a sense of solidarity to all others, and taking up the old inverted Christian fear that Jews were generally hostile to Christians due to the laws of their faith: "Moses ville, att hans folk skulle hata ett annat, som de icke kände, och som alldrig hade gjort dem något emot." (Moses wanted his people to hate another people, whom they did not know, and who had never done them any harm, p. 17). Jews are said to have been a pitiful nation even during their heyday, as evidenced by their failure to develop into a seafaring nation despite living by the sea. The Jews' unwillingness and inability to form an independent state of their own, even as they venerate Moses, the founder of their state and law-giver from centuries ago, is taken as evidence of their inability to contribute to any other people's state - an argument that fed into the theme of Jews only being able to function as a "state within the state."13

In general, the more than 150 pamphlets produced in 1815 in the immediate context of the Grevesmöhlen-Boije-Stabeck-Påhlmann debate are quite repetitive regarding their arguments, be they for or against a Jewish presence in Sweden. The focus is primarily on business practices and secondarily on all kinds of general polemics which do not have much to do with Jews but with the state, publications, newspapers, and public life in general. Religious stereotypes played only a minor role, even though the possibility was repeatedly raised of letting Jews stay in the country on condition that they raise their children in the Christian religion, so as to make the Jewish religion disappear within a gen-

10 Anonymous, Judar äro judar och blifva i evighet judar, eller Det brydsamma försöket att 1815, kosta Sverige hvad det kan, broderligen stöpa judar och svenskar i en form till nästa riksdag (Stockholm: Fr. Cederborgh \& comp., 1815).

11 Anonymous, Viva-Rop för Grevesmöhlen, Påhlman och Judarne (Stockholm: Carl Nyberg, 1815).

12 The rest consists of long quotations from "Erinringar vid herr O.F. Påhlmanns yttrande," a previous publication written in the same spirit.

13 For the development of this accusation, from eighteenth-century French and German authors writing in anti-republican and anti-feudal contexts to its adaptation in the Danish-Norwegian debate about religious tolerance and assimilation, see Frode Ulvund, Religious Otherness and National Identity in Scandinavia, C. 1790-1960: The Construction of Jews, Mormons, and Jesuits as Anti-Citizens and Enemies of Society, Religious Minorities in the North 2 (Berlin: De Gruyter, 2021). 
eration - an option already brought to the table by Wegelin in his initial memorandum to the parliament. This suggests that even though Jews were assigned a long list of mainly negative collective characteristics and collectively exercised business practices, which were in turn said to be grounded in their religion and culture, these characteristics were not necessarily thought to be inheritable. On the other hand, the specific temporality which Christians have placed Jews in is continually evoked: Jews belong to the period of the Hebrew Bible, to the Gospels, to the present and the future, and they are always the same, bearing the blood curse for their mistreatment of Jesus. This context is seldom stated explicitly in the debate itself, but it exists and is visible in the form of legends, religious and entertaining texts, and the like, which were being published and republished at the same time - most of them much more widely disseminated and drawing on much more persistent traditions than the contemporary polemics.

Also in 1815, one of 16 editions of a booklet titled Nådens verkan hos barn was published; this was a translation of the conversion narrative of three Jewish girls who defied their parents' will. Another publication that year, Berättelse, huru judar äro ansedda i England, was an excerpt from a British historiography with a clearly supersessionist and anti-Jewish tone. Svåra bevis emot judarna was the title given to a translated excerpt from Christoph Meiners's study of medieval economic history, the Swedish version framing it as a criticism of "Jewish" business practices. Not just for decades, but for centuries, every couple of years another edition of three medieval legends had been printed, featuring the "Eternal Jew" and reiterating accusations of deicide and of a specific Jewish physiognomy being a "punishment" for mocking and torturing the messiah. All of these texts contributed to what "knowledge" the authors of 1815 had about Jews and informed the debate on expulsion. Different types of text will have had different audiences; the legends and leaflets about conversion will have attracted more and different readers than the political treatises, and definitely more than the extremely self-referential, Stockholm-based publications of 1815 .

But in terms of collective memory on this specific topic, all of these texts contributed to it. The present study aims to reconstruct one part of the archive of antisemitic knowledge in Sweden: printed books from the years 1800 to 1900 dealing with Jewish people, Emancipation, religion, and Jews as a general theme. The archive is a concept from memory studies which allows us to grasp the mechanisms of remembering and forgetting: "The archive is the basis of what 
can be said in the future about the present when it will have become the past."14 Applied to the archive of antisemitism, it is the synopsis of fragments of information, beliefs, notions, and ideas about "Jews," formed out of different sources of information and "half-way between the canon and forgetting." 15 In this corpus, different discourses are represented, along with different actors and levels of discursive power, stored as in an actual archival building in the cultural reference memory.

In 1815, this archive was updated, internationalized, made visible, and considerably enlarged, which becomes clear when the focus is widened from the immediate participants in the debate to the entire print production on Jewish themes. A mixture of religious and racist elements of anti-Jewish hostility becomes visible, not so much from the new texts, arguments, and elements presented in the judefejden, but out of the combined effect of all texts produced on the topic in that year and the surrounding years: medieval and early modern texts handed down for generations in which accusations of deicide and a particular Jewish temporality and transhistorical collective identity were elaborated upon, various forms and aspects of supersessionist conceptions of the relationship between Christianity and Judaism were advanced, and specific ideas about Jewish physiognomy were portrayed in writing and illustrations. All of these need to be considered, both as the intellectual, cultural, and social context of the text production of 1815, and as part of an analysis of antisemitism in nineteenth-century Sweden in general.

The interplay of religious and racist elements in German antisemitism in the first half of the nineteenth century has been discussed under the term Frühantisemitismus (early antisemitism; see discussion below) and has been explained as resulting from the specific situation in the German lands in the period after the Napoleonic Wars. It is debatable whether Sweden experienced a similar phenomenon and, consequently, whether the development of modern antisemitism in Sweden was similar to its development in Germany (and other European countries). At what point did hostility towards Jews change from a religious to a racist phenomenon - or did any such change even take place? This question has been answered differently by scholars from different historiographic fields - medievalists and scholars of church history tend to point out the racist aspects present in pre-modern forms, while scholars of modern and social history tend to focus on the qualitative differences in antisemitic outbreaks after 1800. Regarding

14 Aleida Assmann, "Canon and Archive," in A Companion to Cultural Memory Studies, ed. Astrid Erll, Ansgar Nünning, and Sara B. Young (Berlin: De Gruyter, 2010), 102.

15 Ibid. 
Sweden (and probably also a number of other European countries which are not part of this study), it is important to note that a considerable number of texts which contained "knowledge" about Jews originated in the medieval and Reformation period. Many of these texts contained a concept of distinctively "Jewish" bodies and outer appearances, grounded in the accusation of deicide and extrapolating from it the idea of a distinctive Jewish character and physiognomy.

The events of 1815 - bankruptcies, Napoleonic wars, fierce anti-Jewish propaganda on the continent, the attempt to expel all Jews from Sweden - surely influenced both the actual events in Sweden regarding the Jewish minority and the production of printed matter that year. But it is important to note that in the print production of 1815, almost all the elements of anti-Jewish stereotyping which were to exist throughout the rest of the century can be found combined. This means that as early as 1815, the most important elements of the modernization, adaptation, and merging of medieval and early modern forms of hostility were already on display. More than one author described Jews as a race, ascribed physiognomic markers to Jews collectively, and described Judaism as obsolete and outdated. Where did this comprehensive "knowledge" about Jews, their religion, features, character, and customs come from? Certainly not from observing the few families who had been living in three towns in Sweden since 30 years back. Interest in the hermeneutic Jew was much older and more sophisticated than the immediate debate about Emancipation and immigration. In the present study, this interest and its sources and outcomes will be analysed using the concept of the archive, which I will describe in greater detail in the following section.

The main part of this book is divided into six chapters and a conclusion. The first chapter provides a discussion of the concept of the archive as well as reflections on the international scholarly debate regarding the intersection of religion and race as it relates to the Swedish case specifically. It also provides details on the corpus of sources used in this study. The following four thematic chapters reflect the main themes of the antisemitic archive. The first of these, chapter 2 , on "being cursed," contains those texts which strictly follow medieval models. Chapter 3, on "chosenness," discusses conversion narratives and other texts in which the Jewish religion is the main point of interest and object of hatred; here we also find several text models from the medieval period and the sixteenth and seventeenth centuries, many of them in German and English. The fourth chapter, on "money," consists primarily of Swedish originals which were written by Swedes in the years 1800-1900 as well as court records which were printed publicly. The last thematic chapter, on "bodies and gender," collects the myriad of belletristic texts, novels, romances, plays, and operas which prominently featured Jewish characters, male and female. Following this chapter, the few proJewish contributions in the corpus are mentioned briefly, so as to cover the cor- 
pus as completely as possible. Within each of the chapters, the distinction between Swedish originals and translations from German, Latin, French, and English models is maintained, as is the chronological order of the appearance of the texts.

The concluding, sixth chapter, "The persistence of medieval stereotypes," brings together the analysis of the individual texts from the previous chapters and relates it to the concept of the archive and the question of a distinctive Swedish early antisemitism. 